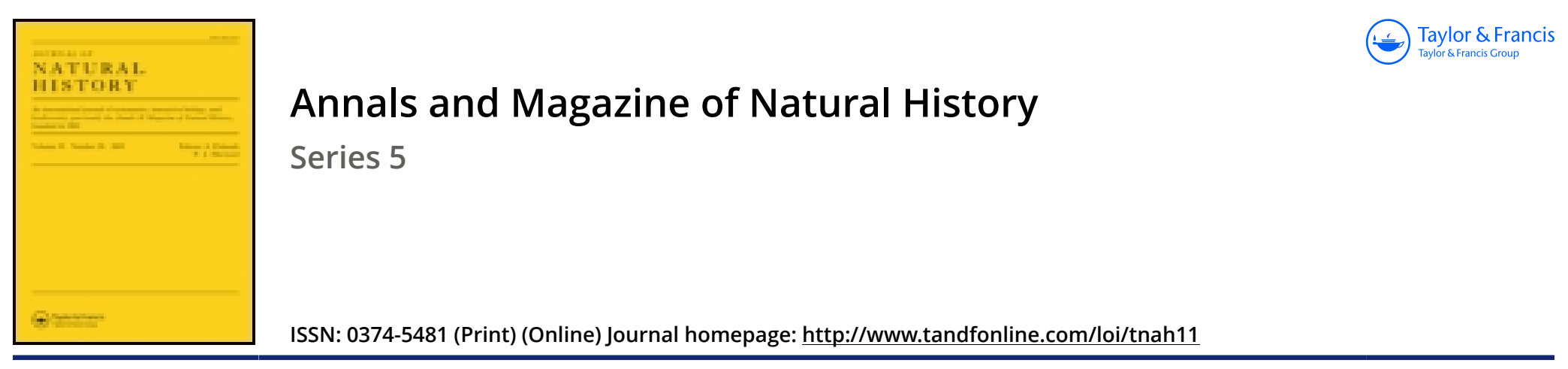

\title{
On the pelagic fauna of the Swiss Lakes
}

\section{Dr. O.E. Imhof}

To cite this article: Dr. O.E. Imhof (1883) On the pelagic fauna of the Swiss Lakes, Annals and Magazine of Natural History, 12:72, 426-427, DOI: 10.1080/00222938309459656

To link to this article: http://dx.doi.org/10.1080/00222938309459656

$$
\text { 曲 Published online: } 09 \text { Oct } 2009 .
$$

Submit your article to this journal $2 \pi$

LII Article views: 3

Q View related articles $\asymp$ 
that these creatures fulfil the function of males, as Fritz Müller very distinctly perceived. Subsequently the cloacal pellicle is cast, carrying with it the skins of the Cyprids, and the cloaca opens.Comptes Rendus, November 5, 1883, p. 1012.

\section{On the Fossil Flora of Greenland. By Prof. O. HeEn.}

Through the author's researches 617 species of fossil plants are now known from Greenland, of which 335 belong to the Cretaceous and 282 to the Tertiary epoch. The Cretaceous plants occur in three distinct stages, described as the beds of Kome, Atane, and Patoot.

In the Kome beds vascular Cryptogamia (especially Gleiohenice) and Gymnosperms (namely 10 Cycadex, forms analogous to the Zamice, and 21 Conifers, including 5 Sequoice) are found almost exclusively. The Dicotyledoneæ are represented only by a single species, Populus primceva. The general character of the flora of these deposits, which may be compared with the Urgonian strata, indicates a subtropical climate.

In the Atane beds there occur, besides vascular Cryptogamia (some of which are arborescent) and Gymnosperms (8 Cycadeæ, 27 Conifers; among others Cycas Steenstrupi with well-doveloped carpels), 90 species of Dicotyledoneæ, the appearance of which was very sudden. Here also the flora indicates a subtropical climate. 'The Atane beds may be compared with the Cenomanian strata.

In the Patoot beds 20 vascular Cryptogamia, 18 Gymnosperms, 5 Monocotyledonex, and 66 Dicotyledonex have been found. Among the Conifers the most abundant species is Sequoia concinna, Heer (branches and fruits), nearly related to the Tertiary Sequoia Couttsice; Sequoia Lanysdorfii, Brgr., a Tertiary species, is also frequently met with. The Dicotyledons consist of birches, alders, elms, fig-trees, walnuts, oaks, and planes (the last two genera in great numbers); then come laurels, cinnamons, aralias, magnolias, dc. \&c. The Patoot beds also contain mariue animals, which enable us to make an exact comparison with the deposits of othor countries, and approximate them to the Upper Senonian of Europe, consequently to the Upper Chalk.

The Tertiary flora of Greenland is derived either from an Eocene deposit or from Lower Miocene beds. It includes in all 282 species, 2 of which also appear in the Chalk; 20 others are derived from Cretaceous plants, but the rest show no relationship to the Cretaceous flora. Moreover, tropical forms are entirely wanting, so that the climate had been profoundly modifed; the mean temperature of the year in Greenland at the epoch of the Lower Miocene must have been about $12^{\circ} \mathrm{C} .\left(=53^{\circ} \cdot 6 \mathrm{~F}\right.$.), as evidenced by the presence of two fan-palms, Magnotia, Supindus, Dalbergia, \&o. The Tertiars fora of Greenland has 114 species like those of Europe-Bibl. Univ., Arch. des Sci. October 15, 1883, p. 355.

\section{On the Pelagic Fanna of the Swiss Lakes.} By Dr. O. F. ImHoF.

The author gives a brief summary of the investigations hitherto 
made in the Swiss lakes, from which it appears that up to the present time there have been found more Entomostraca than true pelagic animals. He then describes the results of his own researches upon several of the lakes. He has fonnd nine new representatives of the pelagic fauna, of microscopic dimensions it is true, but, like the Crustacea, represented by a great number of individuals. Among the Protozoa he cites the four following species, two of which belong to now forms :-

$$
\begin{array}{r}
\text { Mastigophora : Flagellata-Dinobryon sertularia, Ehr. } \\
\text { Ciliflagellata-Peritinium turbulcutum, Imh. } \\
\text { Ceratium reticulatum, Imh. }
\end{array}
$$

Also two new species of Infusoria which live attached to Crustacea, namely :--

Epistylis lacustris, Imh. Acineta elegans, Imb.

Among the Vermes, and especially in the class of Rotatoria, six different forms have likewise been observed :-

Conochilus volvox, Ehr.

Asphanema helvetica, Imh.

Anurcea longispina, Imh.

- spinosa, Imh.

Triarthre, sp.

Polyarthra, sp.

In all therefore twelve species, seven of which are quite new.

Dr. Imhof characterizes the true pelagic forms by means of the following two principal remarks :-

1. The animals which are truly pelagic from their birth to their death always swim freely in the water, never going either to the shore or to tho bottom of the lake, and never touching the surface of the water, so as to aroid coming directly in contact with the atmospheric air.

2. The true pelagic animals carry their ova (with the exception of the winter-egg) either attached to the exterior of the body or in a sort of incubatory cavity until the young individual, whether immediately like its mother or subject to transformation, can quit the envelope of the egg or the incubatory cavity, and lead at once the mode of existence of an accomplishod swimmer.

The author has studied the pelagic fauna of the following lakes:Zurich, Zug, des Quatre-Cantons, Egeri, Katzen, Greifen, Maggiore, Lugano, Como, and Garda._Bibl. Univ., Arch. des Sci. October 15,1883, p. 349 . 